\title{
Low-Cost Aquifer Storage and Recovery: Implications for Improving Drinking Water Access for Rural Communities in Coastal Bangladesh
}

\author{
S. Sultana ${ }^{1}$; K. M. Ahmed ${ }^{2}$; S. M. Mahtab-Ul-Alam³ ${ }^{3}$ M. Hasan ${ }^{4}$; A. Tuinhof ${ }^{5}$; S. K. Ghosh ${ }^{6}$; \\ M. S. Rahman ${ }^{7}$; P. Ravenscroft ${ }^{8}$; and Y. Zheng ${ }^{9}$
}

\begin{abstract}
Fresh water resources are scarce in rural communities in the southern deltaic plains of Bangladesh where both shallow and deep groundwater is frequently brackish, and fresh water ponds have been increasingly salinized by inundation during storm surges and brackishwater aquaculture. Low-cost aquifer storage and recovery (ASR) schemes were constructed at 13 villages in three coastal districts by developing storage in shallow confined fine to medium sand aquifers overlain by variable thicknesses of silt and clay. A typical ASR scheme consisted of a double-chambered graded sand filtration tank with a volume of $19.5 \mathrm{~m}^{3}$ that feeds filtered pond water to four to six large diameter $(d=30.5$ or $56 \mathrm{~cm})$ infiltration wells through PVC pipes fitted with stop valves and flow meters. The infiltration wells were completed at 18-31 m below ground and filled with well-sorted gravel capped with a thin layer of fine sand that acts as a second stage filter. Infiltration rates at 13 sites averaged $3 \mathrm{~m}^{3} /$ day (range: $3-6 \mathrm{~m}^{3} /$ day) over one year of operation. At 11 sites where water was abstracted, the recovery rate ranged from 5 to $40 \%$. The source pond source water frequently had turbidity values of $\geq 100 \mathrm{NTU}$. After sand filtration, the turbidity is typically 5 NTU. Despite this, clogging management involving frequent (monthly to weekly) manual washing to remove fine materials deposited in the sand filtration tank and the infiltration wells is found to be necessary and effective, with post-manual-washing operational infiltration rates restored to annual average values. E. coli counts in recovered water are greatly reduced compared to raw pond water, although $E$. coli is still detected in about half of the samples. Arsenic in recovered water was detected to be at level of $>100 \mu \mathrm{g} / \mathrm{L}$ repeatedly at three sites, suggesting that As risks must be carefully managed and require further investigation. DOI: 10.1061/(ASCE)HE .1943-5584.0001100. (c) 2014 American Society of Civil Engineers.
\end{abstract}

Author keywords: Managed aquifer recharge; Aquifer storage and recovery; Low cost; Climate resilience; Coastal Bangladesh; Groundwater; Water security; Water scarcity; Clogging; Arsenic.

\section{Introduction}

The residents of the southwestern coastal districts Bagerhat, Khulna, and Satkhira in Bangladesh have limited access to safe drinking water due to widespread salinity in surface and groundwater, elevated arsenic in groundwater, and a rapidly growing population [Ahmed et al. 2004; British Geological Survey (BGS) and Department of Public Health Engineering (DPHE) 2001; Khan et al. 2003; Khanom and Salehin 2012]. The shallow aquifer is mostly brackish, with fresh water available in small pockets at shallow depths over limited areas. Rural communities collect rainwater

\footnotetext{
${ }^{1}$ Assistant Professor, Dept. of Geology, Faculty of Earth and Environmental Sciences, Univ. of Dhaka, Curzon Hall Campus, Dhaka 1000, Bangladesh.

${ }^{2}$ Professor, Dept. of Geology, Faculty of Earth and Environmental Sciences, Univ. of Dhaka, Curzon Hall Campus, Dhaka 1000, Bangladesh.

${ }^{3}$ Graduate Research Assistant, Dept. of Geology, Faculty of Earth and Environmental Sciences, Univ. of Dhaka, Curzon Hall Campus, Dhaka 1000, Bangladesh.

${ }^{4}$ Graduate Research Assistant, Dept. of Geology, Faculty of Earth and Environmental Sciences, Univ. of Dhaka, Curzon Hall Campus, Dhaka 1000, Bangladesh.

${ }^{5}$ Hydrologist, Acacia Water, Jan van Beaumontstraat 1, 2805 RN Gouda, Netherlands.

Note. This manuscript was submitted on December 14, 2013; approved on September 9, 2014; published online on November 7, 2014. Discussion period open until April 7, 2015; separate discussions must be submitted for individual papers. This paper is part of the Journal of Hydrologic Engineering, (C) ASCE, ISSN 1084-0699/B5014007(12)/\$25.00.
}

for drinking and cooking during the monsoon season. In the dry season, the communities use pond water, which is being threatened by inundation from cyclonic storm surges and by ponds converted to brackish-water shrimp aquaculture (Ahmed et al. 2009). The region is vulnerable to impacts of climate change and sea level rises [Department of Environment (DOE) 1993].

With abundant monsoon precipitation, aquifer storage and recovery (ASR) in brackish aquifers is an option for climate-resilient, year-round water supplies in coastal Bangladesh (Maliva and Missimer 2010; Pyne 2005). To the best of the authors' knowledge, no prior work has succeeded in demonstrating its utility in this

\footnotetext{
${ }^{6}$ Superintendent Engineer, Dept. of Public Health Engineering, DPHE Bhavan, 14, Shaheed Captain Mansur Ali Sarani, Kakrail, Dhaka 1000, Bangladesh.

${ }^{7}$ Executive Engineer, Dept. of Public Health Engineering, DPHE Bhavan, 14, Shaheed Captain Mansur Ali Sarani, Kakrail, Dhaka 1000, Bangladesh.

${ }^{8}$ WASH Specialist, Water and Environmental Sanitation Section, UNICEF Bangladesh, BSL Office Complex, 1 Minto Rd., Dhaka 1000, Bangladesh; presently, Consultant, Water and Sanitation Program (WSP), c/o World Bank, Plot E 32, Sher-e-Bangla Nagar, Agargaon, Dhaka 1207, Bangladesh.

${ }^{9}$ Professor, School of Earth and Environmental Sciences, Queens College, City Univ. of New York, 65-30 Kissena Blvd., Flushing, NY 11367; and Adjunct Senior Research Scientist, Lamont-Doherty Earth Observatory of Columbia Univ., Palisades, NY 10964; formerly, WASH Specialist, Water and Environmental Sanitation Section, UNICEF Bangladesh, BSL Office Complex, 1 Minto Rd., Dhaka 1000, Bangladesh (corresponding author). E-mail: yan.zheng@qc.cuny.edu; yzheng@1deo.columbia.edu
} 
region because low-cost construction, maintenance, and operational methods are yet to be developed to suit local conditions and technical capacities. Previous attempts in India (Gale et al. 2006) illustrate the difficulty. For example, capturing monsoon runoff through ASR wells was proposed as a concept for an alluvial coastal aquifer in eastern India, with a model simulating an enhanced annual recharge rate up to $0.22 \mathrm{~m}$ (Holländer et al. 2009). However, subsequent field testing of the concept was not successful due to high particle loadings of the source water (Holländer et al. 2009), leading those authors to conclude that low-cost pretreatment technology was needed to lower particulate concentrations of source water.

That clogging emerged as a challenge to ASR application in coastal aquifers in South Asia is not surprising because a reduction in hydraulic conductivity beneath infiltration facilities and around recharge wells is a frequent reason for abandonment of ASR schemes anywhere (Martin 2013). Despite the improved understanding of many physical, chemical, and biological factors that contribute to clogging (Pyne 1994), studies indicate the need for clogging management techniques specific to the aquifer and source-water conditions. Clogging can occur around the well screen, in the filter pack, or in the aquifer (Martin 2013). Considerable uncertainty still exists concerning the causes and degree of clogging in ASR (Maliva and Missimer 2010). Field testing is desirable to address design, operation, and maintenance needs.
In addition to clogging, the risk that reactive organic matter in pond water could mobilize As in shallow groundwater in Bangladesh has been a subject of debate (Datta et al. 2011; McArthur et al. 2011; Neumann et al. 2010; Sengupta et al. 2008). Because pond water frequently contains high levels of pathogens (Hoque 1999; Luby et al. 2008), the potential to reduce microbial contamination through ASR is appealing but has not been evaluated.

To evaluate the feasibility of ASR for rural community water supply in coastal Bangladesh, 13 low-cost ASR schemes were constructed at sites (Fig. 1) chosen to encompass a range of aquifer salinity (Table 1). Managing the risks of clogging by pond water with high particle loadings was considered during the design, construction, and implementation phases, and countermeasures included a sand filtration tank and a sand filter placed at the top of the infiltration wells. Clogging management methods employing powered and/or manual washing were tested to develop operational protocols acceptable to rural communities. Their efficacy was assessed through observation of operational infiltration rates. Monitoring of microbial and chemical water quality, including As, was conducted for source pond water and recovered groundwater for risk assessment.

\section{Study Area and Coastal Aquifer Characteristics}

The region has three distinct seasons: a hot humid summer from March to June, a warm rainy monsoon from July to October,

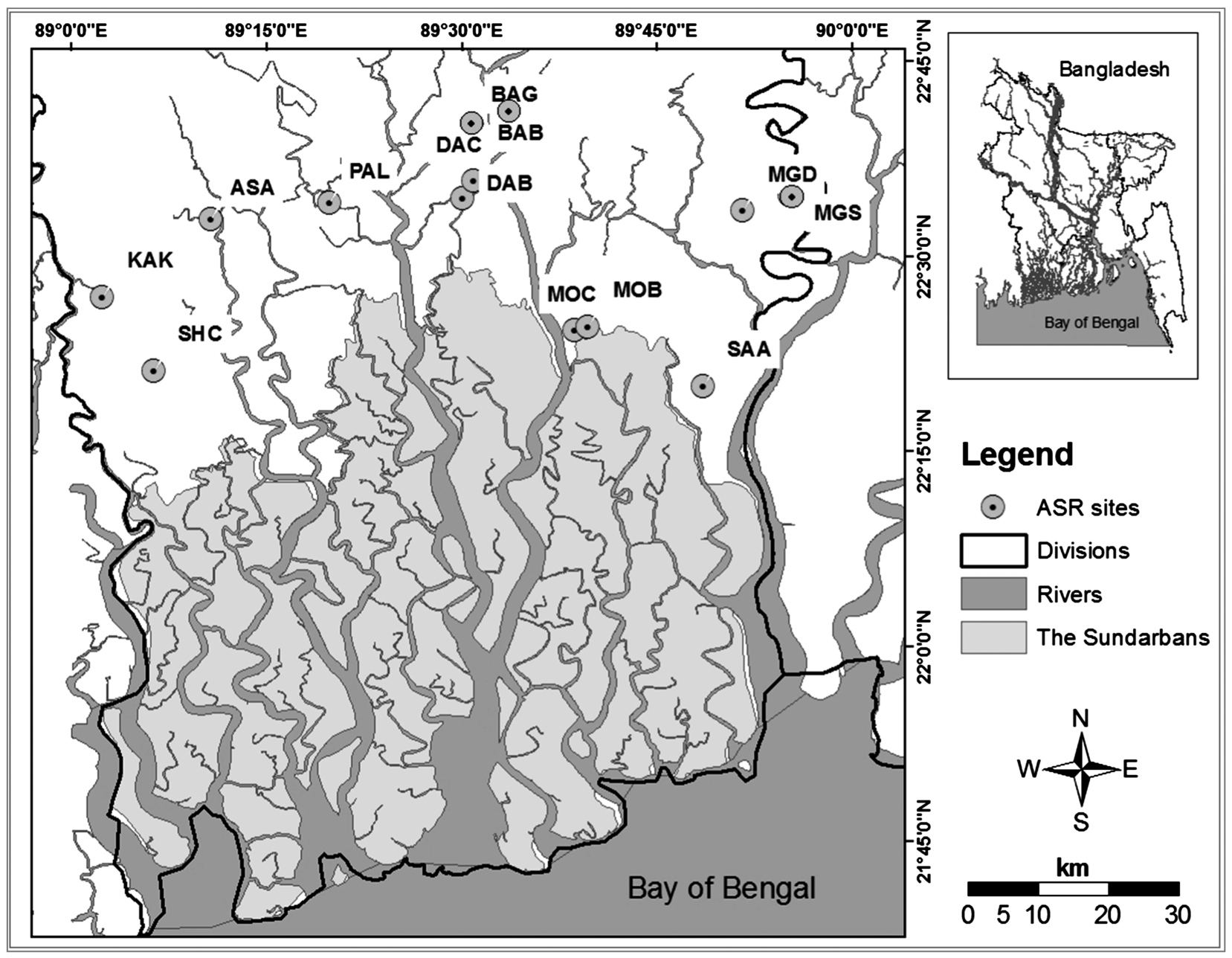

Fig. 1. Locations of 13 aquifer storage and recovery (ASR) sites in three districts of coastal Bangladesh. Target aquifer for ASR is the confined shallow brackish aquifer common in coastal Bangladesh where the thickness of surficial clay layer and the confined shallow aquifer range from 3 to $21 \mathrm{~m}$ and 10 to $>15 \mathrm{~m}$, respectively (Table 1 for aquifer characteristics) 
and a cool dry winter from November to February. Annual rainfall ranges from 1,500 to $2,000 \mathrm{~mm}$ with about $70 \%$ occurring during the monsoon. With an elevation of less than $10 \mathrm{~m}$, southwestern coastal Bangladesh is characterized by a gentle sloping surface shaped by sea level fluctuations in the Holocene (Islam and Tooley 1999). The area is also known for the world's largest mangrove forest, the Sundarbans. Human settlements are located along a large number of rivers and their tributaries flowing into the Bay of Bengal. Rivers are perennial, tidal, and seasonally flushed by monsoonal rain.

The coastal aquifer system in Bangladesh is hydrogeologically complex, characterized by frequent facies changes in both horizontal and vertical directions (Morgan and McIntire 1959), resulting in a heterogeneous distribution of high and low permeability layers [French Geological Survey (BRGM) 2005; Bangladesh Water Development Board (BWDB) 2013]. The aquifer sediments were supplied by the Ganges-Brahmaputra-Meghna rivers in the Quaternary period and overlapped with a deltaic arc (Umitsu 1993).

The target storage zone for the 13 ASR pilot sites is the shallow brackish-water aquifer. It is composed of unconsolidated very fine to medium sand, occasionally interbedded with silty clay (Table 1). Surficial deposits are silty clay, clay, and clay loam. Groundwater levels are tidally influenced and fluctuate from 1 to $2.5 \mathrm{~m}$ below the ground surface. Quartz is the dominant mineral in the aquifer sand, with feldspar, mica, and variable quantities of clay minerals with occasional wood fragments. Aquifer hydraulic conductivity was estimated at the ASA site through rising-head and falling-head slug tests and determined to be approximately $4.5 \mathrm{~m} /$ day (Barker 2013). A hydrochemical study (Bahar and Reza 2010) of 26 shallow groundwater samples from southwestern Bangladesh found that most groundwater is slightly alkaline, with electrical conductivity (EC) ranging from $\sim 1$ to $9.4 \mathrm{mS} / \mathrm{cm}$ and two major hydrochemical facies $\left(\mathrm{Na}^{+}-\mathrm{K}^{+}-\mathrm{Cl}^{-}-\mathrm{SO}_{4}^{2-}\right.$ and $\left.\mathrm{Na}^{+}-\mathrm{K}^{+}-\mathrm{HCO}_{3}^{-}\right)$.

\section{Materials and Methods}

Several designs of low-cost ASR schemes were considered. The ones that prioritized the ease of clogging management were selected for piloting. A typical ASR scheme (Fig. 2) comprises a double-chambered filtration tank, multiple (4-6) large diameter $(30.5 \mathrm{~cm} ; 56 \mathrm{~cm})$ infiltration wells that form a circle with a $3-\mathrm{m}$ radius [Fig. 2(a)], and one abstraction well (diameter $5 \mathrm{~cm}$ ) equipped with a hand pump. To monitor the performance of the ASR, two piezometers (diameter $3.8 \mathrm{~cm}$ ) are installed inside the infiltration well screened at the top and bottom of the screened section of the well [Fig. 2(c)], with an additional four piezometers placed at a 1-m radial distance away from the infiltration wells [Fig. 2(a)]. Local drillers employed direct circulation rotary and reverse circulation percussion drilling methods that used waterbased drilling mud built from clay with cow dung as additives. Washing was carried out immediately after drilling to remove drilling mud from the borehole to prevent permanent formation damage. Washing continued until the water became clear, usually after about $1-1.5 \mathrm{~h}$. Gravel was placed inside the well up to the top and to $1 \mathrm{~m}$ above the screen section in the annular space.

Turbidity of pond water at intake and after pretreatment at the sand filtration tank, and of recovered groundwater from the abstraction well [Fig. 2(a)] were monitored daily with locally-made turbidity tubes (Science workshop, University of Dhaka, Dhaka, Bangladesh) based on visual comparison scale. A turbidity meter (Lutron model TU-2016, Taipei, Taiwan) was used to calibrate the turbidity tubes. Electrical conductivity (EC), temperature, and $\mathrm{pH}$ were also monitored daily using a portable conductivity meter
(HANNA HI 8733, Europe, Romania) and pH meter (HANNA HI 98127, Europe, Romania). When the EC of the abstracted groundwater drops below the potable water limit $(1,000 \mathrm{mg} / \mathrm{L}$ chloride, or about $2 \mathrm{mS} / \mathrm{cm}$ ), the local communities are allowed to collect water from the ASR. The volume of abstraction is recorded by a flow meter attached to the sprout of the hand pump of the abstraction well. Water levels in all the piezometers are recorded daily.

The initial (and presumed maximum) infiltration rates were determined through falling head tests immediately after construction was completed, while the operational infiltration rates were determined from daily monitoring data. For falling head tests, infiltration wells were first topped up with filtered pond water from the filtration tank by opening the gate valves to fully saturate the gravel. Then the rate of drop of the water level was measured using a stopwatch. This rate and the infiltration well diameter allowed an estimation of the presumably maximum infiltration rate before operation. Infiltration was monitored daily with a flow meter installed between the filtration tank and the infiltration well. The daily operation infiltration rate was calculated by dividing the total volume of water by the number of days since infiltration started.

A preliminary water quality assessment was carried out. E. coli was measured on May 24, 2013, Sept 20, 2013, and March 14, 2014, for raw pond water and abstraction well water samples using compact Dry Nissui EC 240 plates (Tokyo, Japan) by adapting the manufacturer's protocol (Kodaka et al. 2006) for water analysis by either pipetting $1 \mathrm{~mL}$ of the water sample to the plates or adding a membrane filter after the 100-mL water sample has been processed. Care was taken to maintain sterile conditions by using alcohol wipes. Pond water samples collected before and after the filtration tank plus groundwater samples from the abstraction wells were obtained on four dates: July 11, 2012, September 15, 2012, March 30, 2013, and July 12, 2013. Samples were filtered through 0.45-m membrane syringe filters and were acidified to $1 \%$ nitric acid and then sent for analysis of cations and trace elements including As, Fe, and Mn at Swiss Federal Institute of Aquatic Science and Technology (EAWAG), Zurich, Switzerland by inductively coupled plasma optical emission spectrometry (ICP-OES) following standard protocols. A nonacidified aliquot was sent for $\mathrm{Cl}$ analysis by ion chromatograph following standard protocols at EAWAG. Arsenic in abstracted groundwater was monitored weekly using the EconoQuick test kit (Industrial Test Systems, Rock Hill, South Carolina; George et al. 2012).

\section{Design and Construction of ASR Schemes}

The design for the ASR schemes included a sand filtration tank to pretreat pond water; four to six large diameter infiltration wells; and an abstraction well equipped with a hand pump. Schematic designs of the sand filtration chamber, infiltration wells, piezometers, and the abstraction well are shown in Fig. 2. The cost including material and labor for the ASR schemes ranged from US\$5,000 to US\$7,000, with the abstraction well (US\$ 100) only a small percentage of the cost.

\section{Sand Filtration Tank}

The purpose of the tank is to remove or reduce suspended solids, organic matter, pathogens, and other compounds. The filtration tank (dimension: $4.3 \times 2.1 \times 2.1 \mathrm{~m}^{3}$ ) is double chambered with sand in one chamber and filtered water in another [Fig. 2(b)]. It is either placed at ground level or elevated up to $3 \mathrm{~m}$ to increase the hydraulic head for infiltration. To prevent leaves, fish, and other debris from entering, a screen is placed at the intake point 


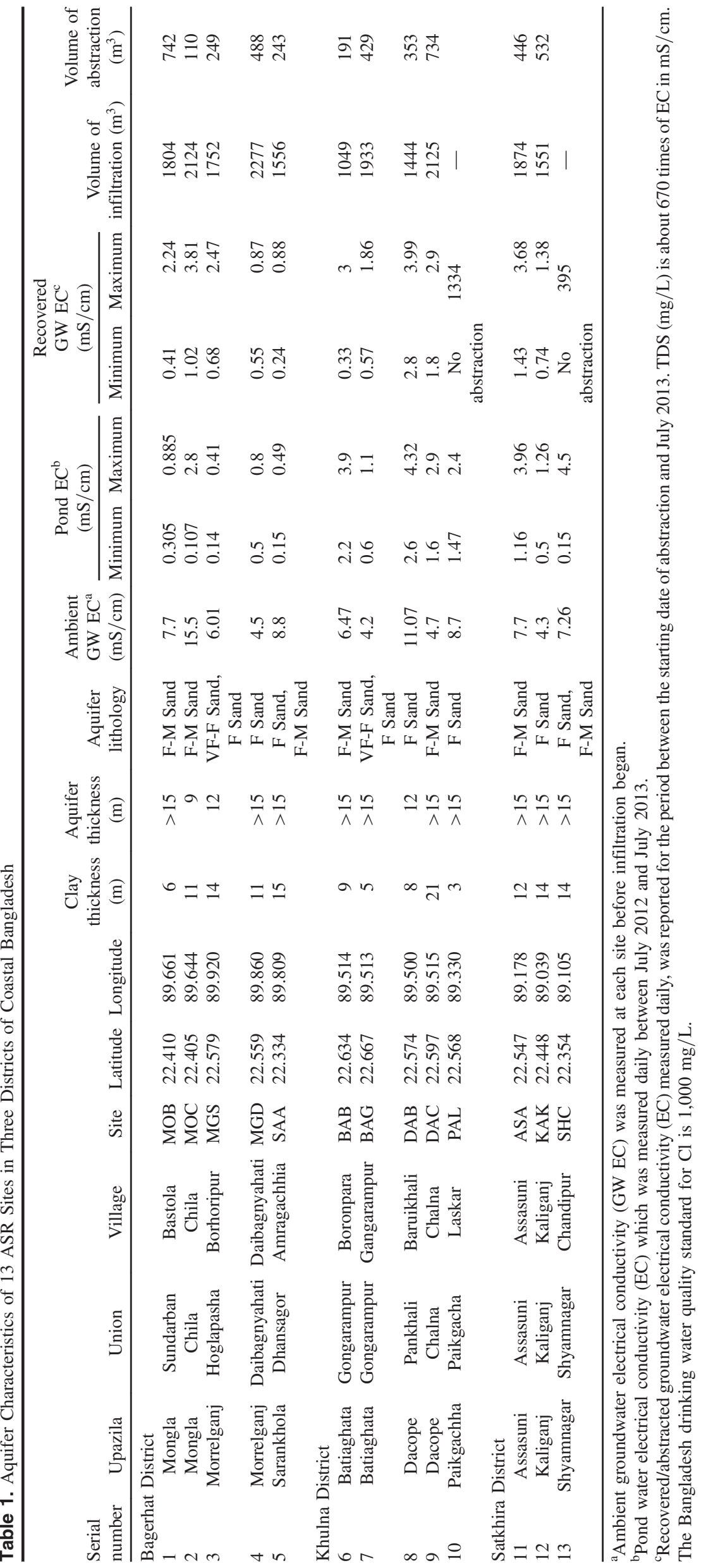



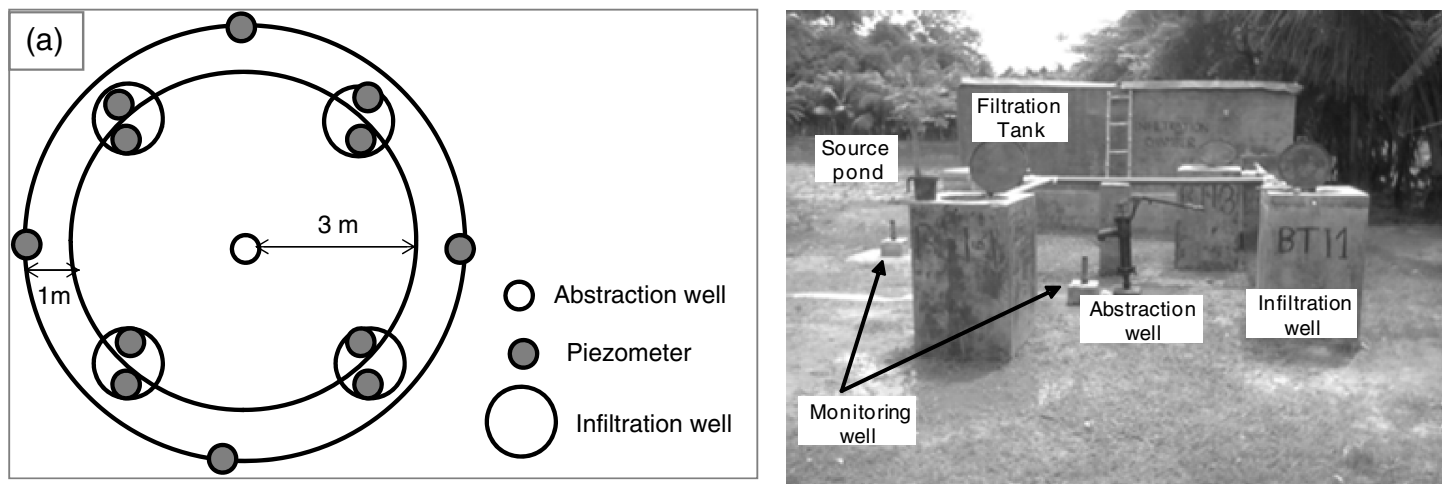

(b)
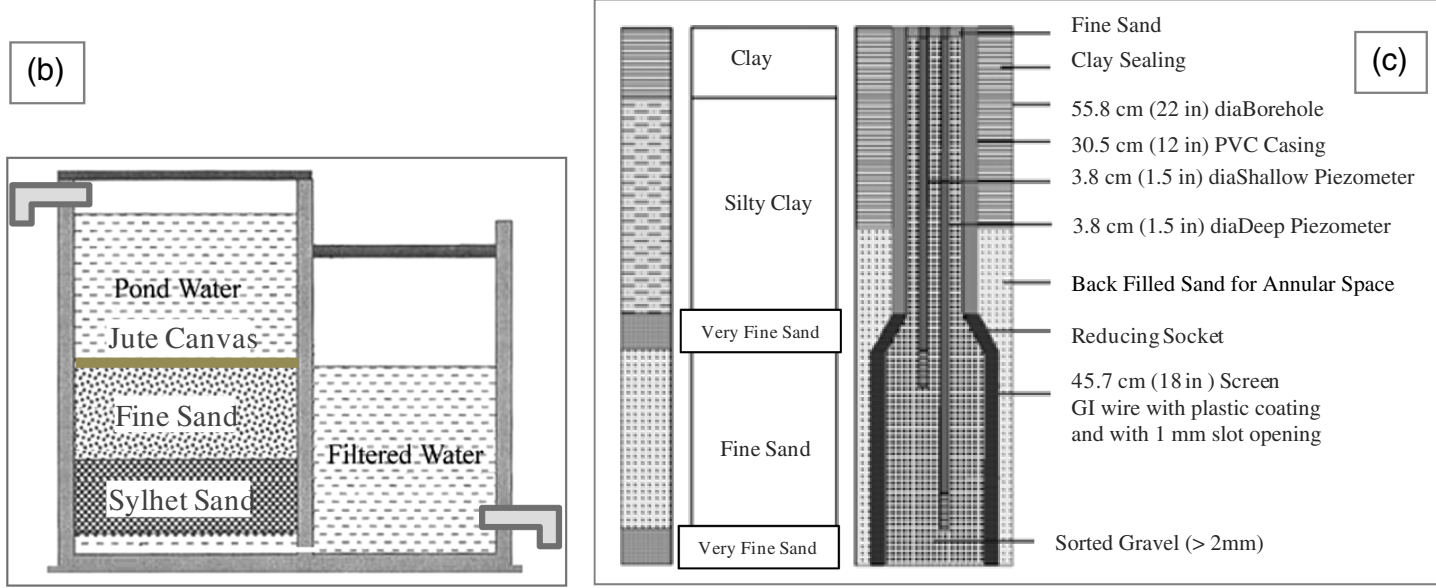

Fig. 2. Design components of the low-cost ASR schemes piloted in coastal Bangladesh: (a) schematic diagram illustrating the configuration of key components of a representative ASR scheme with four infiltration wells, one abstraction well in the center, and four additional piezometers, with a photograph of the ASR scheme from the BAG site; (b) schematic drawing of sand filtration chamber to pretreat pond water; (c) schematic drawing of a large diameter infiltration well; the lithology represents what is typically encountered in coastal Bangladesh (Table 1 for aquifer characteristics)

of a suction pump (nominal discharge $0.002 \mathrm{~m}^{3} / \mathrm{s}$ at a head of $38 \mathrm{~m}$ ) that lifts water from the pond. The sand filter has coarse brown sand $(0.5-2 \mathrm{~mm})$ from Sylhet at the bottom and a finer sand $(<0.5 \mathrm{~mm})$ at the top. The coarse Sylhet sand is brought by boat from northeastern Bangladesh; the finer sand is locally sourced. On top of the sand filter, a 'Geojute' mesh (a biodegradable fabric woven from jute fibers available locally) is placed to retain the suspended solids. Water slowly percolates downward, removing particles and pathogens, with no chemical treatment. The filtered water is directed to infiltration wells under gravity via a pipe network fitted with stop valves and flow meters [Fig. 2(a)].

\section{Infiltration Wells}

Most infiltration wells were constructed with a diameter $56 \mathrm{~cm}$ but some had a diameter of $30.5 \mathrm{~cm}$. To minimize clogging risk, a second stage of filtration was included in the infiltration wells [Fig. 2(c)]. A 15-cm layer of fine sand was placed in the top section of the well filled with well-sorted gravel of $>2 \mathrm{~mm}$ diameter. The upper section of the well was cased with a 30.5-cm-diameter PVC pipe, with length ranging from 3 to $21 \mathrm{~m}$ depending on surficial clay layer thickness [Fig. 2(c)]. The casing is connected to the screen below through a reducing socket. The screen is made from a mild steel rod frame wrapped with plastic-coated galvanized iron (GI) wire mesh with $1 \mathrm{~mm}$ openings. To prevent percolation of untreated water, sand recovered during drilling is used to fill the annular space at least $30 \mathrm{~cm}$ above the screen, and then sealed with local clay.

\section{Abstraction Well}

The abstraction well, a conventional suction-mode hand tubewell, is placed at the center of a 3-m-radius ring of infiltration wells [Fig. 2(a)] and is screened over about half the thickness of the target aquifer. As elsewhere in the world, separate recovery wells are used to exploit the aquifer's natural filtration ability to remove nutrients and microorganisms during storage (McQuarrie and Carlson 2003; Pavelic et al. 2005; Pyne 2002).

\section{Operation and Maintenance}

Engagement of the community is critical because pond water is often the only fresh water source during the dry season. Therefore, community consent is required for infiltration in the ASR systems. To prevent clogging by air entrainment during infiltration, which is most likely when water is allowed to cascade into the well, a flowcontrol valve was connected to the deeper piezometer installed inside the infiltration well at a level below the static water level of infiltration well to maintain a positive pressure. The maintenance tasks mostly needed for management of cogging are as follows.

\section{Maintenance of the Sand Filtration Tank}

The Geojute canvas on top of the sand filter is washed weekly to remove fine materials [Fig. 3(a)]. Additionally, fine sand below the Geojute canvas is manually washed and replaced every 4-6 weeks when the operational infiltration rate shows a noticeable decline. 

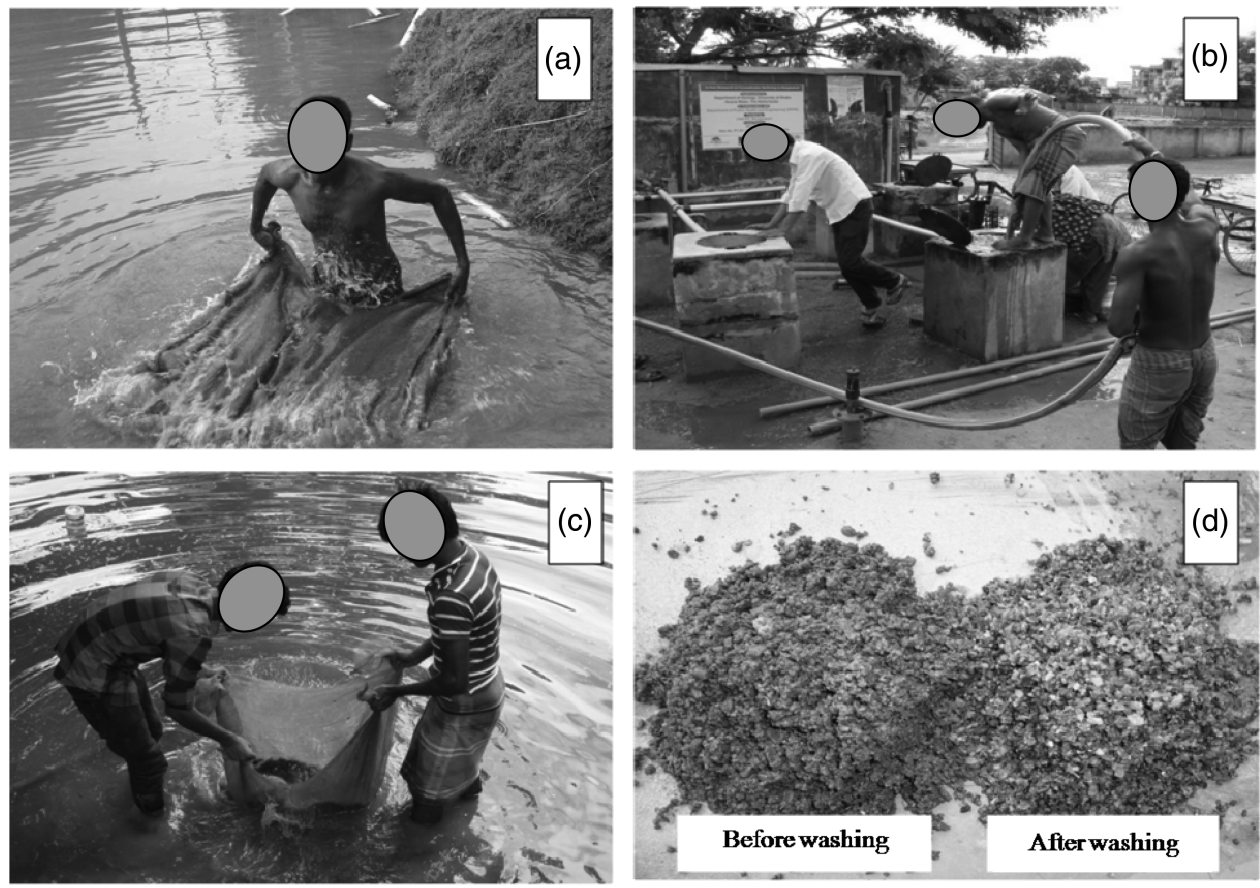

Fig. 3. Photographs of clogging management methods: (a) washing the 'Geojute' cover of the sand filtration chamber; (b) power backwashing of gravel pack of infiltration wells that costs about US\$100 each time; (c) manual washing of gravel pack of infiltration well that costs about US\$10 each time; (d) difference of gravel before and after manual washing

\section{Maintenance of Infiltration Wells}

The sand and gravel are periodically backwashed, and when necessary, replaced from the upper part of the casing. The top fine sand layer is replaced once a month. When there is a reduction in the operational infiltration rate, power backwashing is performed using a mechanical pump (nominal discharge $0.008 \mathrm{~m}^{3} / \mathrm{s}$ at a head of $38 \mathrm{~m}$ ) by injecting pond water through a $10 \mathrm{~m}$ hose inserted into the infiltration wells [Fig. 3(b)]. This energized flow of water stirs up the gravel, removing the fines. Power backwashing was performed typically every 6 months. Although this method is quick, it can result in loss of large amounts of gravel. Moreover, contractors need to be hired at a cost of US $\$ 100$ each time. Starting in July 2013, a simpler approach was adopted involving manually digging out the gravel to a depth of about $1.5 \mathrm{~m}$, and then washing with water [Fig. 3(c)]. Visual comparison of gravels before and after washing indicated that fine materials have been removed [Fig. 3(d)]. This method costs about US\$10, results in no gravel loss, and can be done by the community themselves. Manual washing is carried out at intervals of 1 to 2 months.

\section{Results and Discussion}

\section{Recovery of Fresh Water}

Water with a TDS of $<600 \mathrm{mg} / \mathrm{L}$ (EC c. $1 \mathrm{mS} / \mathrm{cm}$ ), is generally considered to be palatable. Water becomes increasingly unpalatable when TDS exceeds $1,000 \mathrm{mg} / \mathrm{L}$ (EC c. $2 \mathrm{mS} / \mathrm{cm}$ ). Bangladesh drinking standard allows for $1,000 \mathrm{mg} / \mathrm{L}$ of chloride in coastal area. However, fresh water with TDS $<1,000 \mathrm{mg} / \mathrm{L}$ is so scarce in southwestern coastal Bangladesh that villagers often tolerate drinking water with EC up to $4 \mathrm{mS} / \mathrm{cm}$ (TDS 2,700 mg/L).

The EC of pond water at 13 sites (Table 1) ranged from very fresh $(0.1 \mathrm{mS} / \mathrm{cm})$ to brackish $(4.5 \mathrm{mS} / \mathrm{cm})$, depending on distance to tidal river channels or brackish-water shrimp cultivation.
EC varied over time and were higher during dry season than the monsoon when pond water is diluted by rainwater. The ambient shallow groundwater in the target aquifer is brackish with EC ranging from 4.2 to $15.5 \mathrm{mS} / \mathrm{cm}$ (equivalent $\mathrm{TDS} \sim 3,000$ to $10,000 \mathrm{mg} / \mathrm{L}$, Table 1). The recovered water is usually fresh but is occasionally slightly brackish, with EC ranging from 0.24 to $4 \mathrm{mS} / \mathrm{cm}$ (Table 1), reflecting different degrees of freshening.

Daily monitoring of the EC of the abstraction well as the infiltration progressed was used to guide when abstraction could begin for community water supply. At the 11 sites where water has been abstracted, the infiltration volume ranged from 394 to $2,277 \mathrm{~m}^{3}$. The recovery rate, estimated based on the volume of water abstracted and the volume of water infiltrated (Table 1) ranged from 5 to $40 \%$. Sites were not ready for abstraction at the same time because the volume of infiltration and the ambient groundwater salinity differed (Table 1). In two cases, no water was abstracted in 2013 due to high EC in recovered water (Table 1), although abstraction was possible in 2014 after two summers of infiltration.

\section{Clogging Risks and Management Efficacy}

There is an inherent risk of clogging because pond water turbidity ranges from 5 to 160 NTU with a mode of $\sim 100$ NTU (Table 2). Higher values of pond water turbidity were observed in the early monsoon, and lower values during the peak monsoon. After pretreatment in the sand tank, the turbidity of filtered pond water decreased significantly at all sites but was still detectable (Table 2). Based on the modal value of turbidity of filtered pond water, the sites have been categorized as at low (0 NTU), medium (5 NTU) and high (>10 NTU) risk for clogging of infiltration wells (Table 2). Studies of an ASR site from Bolivar, South Australia, which used wastewater as source of injection, indicated low risks of short-term and long-term clogging when turbidity is $<3$ NTU, total nitrogen $<10 \mathrm{mg} / \mathrm{L}$, and $\mathrm{pH}<7.2$ (Pavelic et al. 2007a, b). Therefore, even though the risks of short-term clogging have been 


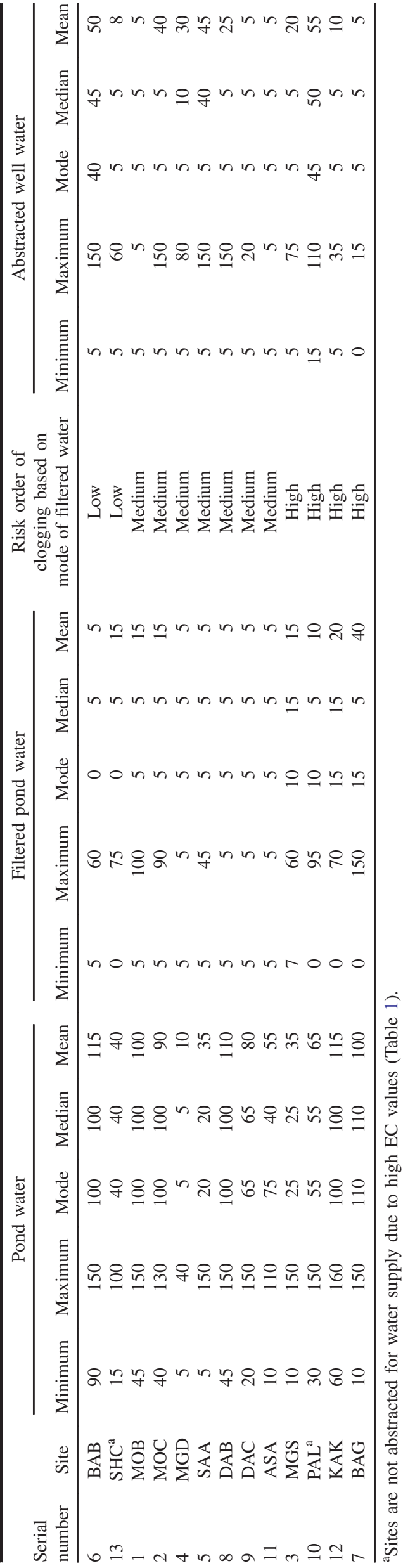

reduced by sand filtration, there is a need to manage clogging for the infiltration wells (see subsequent discussion). Furthermore, recovered well water has a turbidity mode of 5 NTU (Table 2) and can also be a risk factor for clogging over long term.

The initial and presumably maximum infiltration rates, determined through falling head tests, varied from 6 to $20 \mathrm{~m}^{3} / \mathrm{d}$ (assuming that infiltration during each day would be 24 h, Fig. 4). Except for three sites (BAB, SAA, and DAC, Fig. 4), the actual initial operational infiltration rates were lower than the initial rates determined from falling head tests, with site SHC showing the largest difference (Fig. 4). The operational infiltration rates are expected to be lower than the maximum rates because infiltration was intermittent, occurring only during the working hours of the pump operators, and subject to interruption due to pump failures and power outages. Furthermore, there is not enough pond water for infiltration as monsoon rain wanes because villagers do not want to divert pond water for ASR systems as water level drops in the pond.

Changes in operational infiltration rates were used to assess the efficacy of clogging management methods. Of particular concern is that the operational infiltration rates after one year had significantly declined compared to the initial operational rates (Fig. 4), especially for four sites where the reduction ranged from 59 to $80 \%$. The reductions in infiltration rates were highly variable across the sites (Fig. 4) and do not correspond to the turbidity risks from filtered pond water categorized as low, medium and high (Table 2). This suggests that reduction in infiltration rates is influenced by factors other than the turbidity in filtered water and that the location of clogging is the infiltration well. To test whether washing of infiltration wells could reverse the decline in infiltration rates, pumped backwashing [Fig. 3(b)] was used first at a few sites. This did improve the operational infiltration rates although data were not collected immediately after backwashing and thus could not be reported. Manual washing of gravel [Figs. 3(c and d)] took place in July 2013 and resulted in large increases in infiltration rates at all sites (Fig. 4). At site MGD, which had a $43 \%$ reduction in infiltration rate, the infiltration rate has rebounded to about $9 \mathrm{~m}^{3} / \mathrm{d}$ post washing, similar to the initial operational infiltration rate. However, most sites were not restored to the initial operational infiltration rates but rather restored to the average operational infiltration rates (Fig. 4), which ranged from 3 to $6 \mathrm{~m}^{3} / \mathrm{d}$ over one year between July 2012 and July 2013. Although manual washing was successful, it is possible that clogging may become severe in the future and is consequently being monitored.

The pond water $\left(28-36^{\circ} \mathrm{C}\right)$ is warmer than groundwater $\left(27-30^{\circ} \mathrm{C}\right)$ but this does not appear to have changed the viscosity of the water enough to be of great concern. The pond water $\mathrm{pH}$ ranged from 7.5 to 8.5 , similar enough to groundwater with $\mathrm{pH}$ ranging between 6.6 and 7.5 .

\section{Drinking Water Quality}

The drinking water withdrawn from the abstraction wells showed improvement in terms of E. coli compared to pond water. Pond water from all 13 sites, sampled on three dates, contained E. coli counts that were too high to quantify (>100 cfu/100 mL, Table 3 ). In comparison, the recovered groundwater, while not free of E. coli, has significantly reduced levels and occurrence rates of $E$. coli (Table 3). Nevertheless, about half of the samples still displayed nonzero E. coli counts (Table 3), suggesting a need for disinfection of the recovered water to ensure safety. Alternatively, abstraction of groundwater could be deferred for a period of time to take advantage of the aquifer's natural process to disinfect, although this requires further study. 


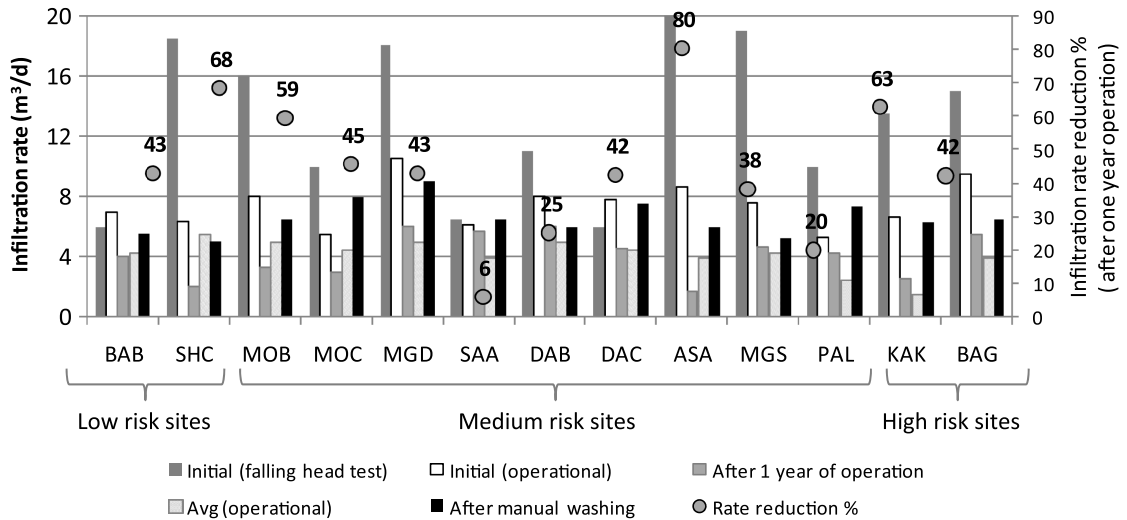

Fig. 4. The bars (left y-axis) from left to right are: initial presumably maximum rate of infiltration estimated from the falling head test, initial operational infiltration rate, rate of infiltration after one year of operation, average operational rate of infiltration, and rate of infiltration after manual washing of gravel in July, 2013; the percentage of reduction in the rate of infiltration (right y-axis) between initial values and after one year of operations are indicated as circles, with numerical values above the circles showing the percentage for each site

After the oxygenated and filtered pond water infiltrates into the reducing aquifer, it becomes reducing as evidenced by presence of Fe and $\mathrm{Mn}$ in abstraction well water (Table 4). Concentrations of Fe in recovered water were generally the highest in July 2012 and remained high in September 2012 during the infiltration period of the first year of ASR scheme's operation but were considerably lower during the infiltration period of the second year in July 2013 (Table 4). Samples collected in March 2013 fall within the abstraction period, with concentrations of Fe generally below $2 \mathrm{mg} / \mathrm{L}$. This level of iron is common in Bangladesh groundwater and may be tolerated although taste may be of concern for population sensitive to metallic taste of water. The concentrations of $\mathrm{Mn}$ were $>0.4 \mathrm{mg} / \mathrm{L}$ at 3 sites in March 2013 (Table 4), although only

Table 3. Comparison of E. coli Levels in Raw Pond Water and Abstracted Well Water

\begin{tabular}{|c|c|c|c|c|c|}
\hline \multirow{2}{*}{$\begin{array}{l}\text { Serial } \\
\text { number }\end{array}$} & \multirow[b]{2}{*}{ Site } & \multirow[b]{2}{*}{ Source } & \multicolumn{3}{|c|}{ E. coli counts $/ 100 \mathrm{~mL}$} \\
\hline & & & $24 / 05 / 2013$ & 20/09/2013 & $14 / 03 / 2014$ \\
\hline \multirow[t]{2}{*}{1} & \multirow[t]{2}{*}{ MOB } & Pond & $>100$ & $>100$ & 52 \\
\hline & & Well & 1 & 16 & 5 \\
\hline \multirow[t]{2}{*}{2} & \multirow[t]{2}{*}{ MOC } & Pond & $>100$ & $>100$ & $>100$ \\
\hline & & Well & 1 & 18 & 0 \\
\hline \multirow[t]{2}{*}{3} & \multirow[t]{2}{*}{ MGS } & Pond & $>100$ & 96 & $>100$ \\
\hline & & Well & 3 & 0 & 37 \\
\hline \multirow[t]{2}{*}{4} & \multirow[t]{2}{*}{ MGD } & Pond & $>100$ & 52 & $>100$ \\
\hline & & Well & 0 & 0 & 0 \\
\hline \multirow[t]{2}{*}{5} & \multirow[t]{2}{*}{ SAA } & Pond & $>100$ & $>100$ & 16 \\
\hline & & Well & 0 & 1 & 0 \\
\hline \multirow[t]{2}{*}{6} & \multirow[t]{2}{*}{ BAB } & Pond & $>100$ & $>100$ & $>100$ \\
\hline & & Well & 38 & 1 & 0 \\
\hline \multirow[t]{2}{*}{7} & \multirow[t]{2}{*}{ BAG } & Pond & $>100$ & $>100$ & $>100$ \\
\hline & & Well & 0 & 0 & 0 \\
\hline \multirow[t]{2}{*}{8} & \multirow[t]{2}{*}{$\mathrm{DAB}$} & Pond & $>100$ & $>100$ & $>100$ \\
\hline & & Well & 0 & 0 & 0 \\
\hline \multirow[t]{2}{*}{9} & \multirow[t]{2}{*}{ DAC } & Pond & $>100$ & $>100$ & $>100$ \\
\hline & & Well & 0 & 0 & 0 \\
\hline \multirow[t]{2}{*}{10} & \multirow[t]{2}{*}{ PAL } & Pond & $>100$ & $>100$ & $>100$ \\
\hline & & Well & 8 & 23 & 0 \\
\hline \multirow[t]{2}{*}{11} & \multirow[t]{2}{*}{ ASA } & Pond & $>100$ & $>100$ & 26 \\
\hline & & Well & 3 & 0 & 0 \\
\hline \multirow[t]{2}{*}{12} & \multirow[t]{2}{*}{ KAK } & Pond & $>100$ & $>100$ & $>100$ \\
\hline & & Well & 2 & 13 & 0 \\
\hline \multirow[t]{2}{*}{13} & \multirow[t]{2}{*}{ SHC } & Pond & $>100$ & $>100$ & $>100$ \\
\hline & & Well & 25 & 1 & 1 \\
\hline
\end{tabular}

one site (DAB) used for water supply had Mn level of $0.73 \mathrm{mg} / \mathrm{L}$, which is a health concern (Wasserman et al. 2006). Monitoring of $\mathrm{Fe}$ and $\mathrm{Mn}$ on a regular basis is desirable to determine whether Fe and Mn treatment will be necessary.

The occurrence of arsenic in the recovered water is a significant concern. Laboratory analysis of abstracted water collected in March 2013 showed that 11 of 13 sites produced $<10 \mu \mathrm{g} / \mathrm{L} \mathrm{As}$, and 2 sites (MGS and DAB) between 10 and $50 \mu \mathrm{g} / \mathrm{L} \mathrm{As}$, and none $>50 \mu \mathrm{g} / \mathrm{L}$ As (the Bangladesh standard). At MGD and DAB, the concentrations of $\mathrm{Fe}$ and $\mathrm{As}$ are correlated, with high levels of $\mathrm{Fe}$ $(>10 \mathrm{mg} / \mathrm{L})$ and As $(>100 \mu \mathrm{g} / \mathrm{L})$ found during the first infiltration period in 2012 (Fig. 5). Such correlations suggest that As may have been mobilized to groundwater through reductive dissolution of iron oxyhydroxide upon infiltration of pond water, although there appears to be immobilization during the abstraction period in the dry period of 2013. Monitoring data obtained by the EconoQuick kit between July 2012 and May 2014 revealed As $>50 \mu \mathrm{g} / \mathrm{L}$ in abstracted water at six sites and that the occurrence is not limited to the infiltration periods (Fig. 6). Even if only considering As occurrence in recovered water excluding the infiltration period, persistent high median values of As at $250(n=24), 100$ $(n=50)$, and $250(n=12) \mu \mathrm{g} / \mathrm{L}$ were found at sites MGD, DAB, and SHC, respectively. Monitoring of EC (Fig. 6) indicates freshening over time and does not correspond to the large As increase at these sites, suggesting that As release is not caused by mixing. The chemical change in groundwater associated with infiltration of pond water rich in nutrients and natural organic matter requires further study. Depending on the mechanisms of As mobilization, effective removal of biological oxygen demand in the filtered pond water, combined with measurement of sediment-mobilizable As concentrations (Jung et al. 2012), may be useful management approaches to reduce As risks in future ASR applications.

\section{Long-Term Risks of Clogging: Turbidity in Abstracted Groundwater}

Sand filtration significantly reduced particle loadings at most sites, but at BAB and PAL, the modal values of turbidity in recovered water (40 and $45 \mathrm{NTU}$, Table 2) are higher than in filtered pond water ( 0 and 10 NTU respectively). Recovered water from all other sites showed consistently low turbidity (mode: 5 NTU, Table 2). This indicates that processes in the infiltration wells or the aquifer may contribute to the clogging risk. This may have been caused by 
Table 4. Concentrations of Arsenic, Iron, Manganese, and Chloride in Raw Pond Water and Groundwater from Abstraction Wells

\begin{tabular}{|c|c|c|c|c|c|c|c|c|}
\hline \multirow[b]{3}{*}{ Site } & \multicolumn{8}{|c|}{ Concentration of arsenic $(\mu \mathrm{g} / \mathrm{L})$} \\
\hline & \multicolumn{4}{|c|}{ Pond water before filtration } & \multicolumn{4}{|c|}{ Abstracted groundwater } \\
\hline & $11 / 7 / 2012$ & $15 / 9 / 2012$ & $30 / 3 / 2013$ & $12 / 7 / 2013$ & $11 / 7 / 2012$ & $15 / 9 / 2012$ & $30 / 3 / 2013$ & $12 / 7 / 2013$ \\
\hline MOB & 4 & 2 & 7 & 6 & bdl & 1 & 1 & 1 \\
\hline MOC & 1 & bdl & 7 & 3 & 29 & 11 & 5 & 5 \\
\hline MGS & 5 & 1 & 6 & 5 & 15 & 8 & 15 & 12 \\
\hline MGD & 3 & bdl & 3 & 4 & 463 & 284 & 9 & 16 \\
\hline SAA & 3 & bdl & 2 & 3 & 18 & 12 & 4 & 11 \\
\hline $\mathrm{BAB}$ & 3 & bdl & 4 & 5 & bdl & bdl & 1 & 1 \\
\hline BAG & 5 & 6 & 6 & 19 & bdl & bdl & 3 & 2 \\
\hline DAB & 4 & 2 & 3 & 4 & 129 & 133 & 49 & 97 \\
\hline DAC & 2 & 1 & 4 & 3 & 8 & 4 & 5 & 4 \\
\hline PAL & 2 & 1 & 4 & 5 & 3 & 2 & 6 & 4 \\
\hline ASA & bdl & bdl & 2 & 2 & 6 & 6 & 4 & 3 \\
\hline KAK & bdl & 5 & 7 & 21 & bdl & bdl & 1 & 4 \\
\hline $\mathrm{SHC}^{\mathrm{a}}$ & bdl & bdl & 5 & 4 & bdl & 1 & 2 & 2 \\
\hline Site & \multicolumn{8}{|c|}{ Concentration of iron $(\mathrm{mg} / \mathrm{L})$} \\
\hline MOB & 1.4 & 0.6 & 0.2 & 0.1 & 3.3 & 0.8 & 1.0 & 0.1 \\
\hline MOC & bdl & 0.5 & 0.3 & 0.1 & 37.5 & 13.1 & 1.8 & 0.1 \\
\hline MGS & 0.5 & 4.7 & 0.2 & 0.9 & 6.2 & 0.8 & 0.4 & 3.6 \\
\hline MGD & 0.1 & bdl & 0.2 & 0.2 & 26.6 & 15.7 & 1.6 & 2.2 \\
\hline SAA & 4.2 & 1.0 & 0.8 & 0.8 & 5.1 & 4.3 & 0.1 & 1.2 \\
\hline $\mathrm{BAB}$ & bdl & bdl & 1.6 & 0.5 & 1.1 & 2.3 & 2.0 & 1.1 \\
\hline BAG & 1.0 & bdl & 0.3 & 0.8 & 1.6 & 1.6 & 1.7 & 1.7 \\
\hline DAB & 1.5 & 0.7 & 0.2 & 0.1 & 16.4 & 14.1 & 2.0 & 1.0 \\
\hline DAC & 1.4 & 5.2 & 0.2 & 0.1 & 3.6 & 5.0 & 0.9 & 0.8 \\
\hline PAL & bdl & 0.0 & 1.4 & 0.0 & 4.5 & 3.4 & 0.2 & 0.0 \\
\hline ASA & 0.2 & 0.0 & 0.6 & 0.2 & 1.0 & 1.9 & 1.2 & bdl \\
\hline KAK & 1.2 & 0.9 & 0.1 & 0.2 & 3.0 & 1.7 & 0.4 & 0.3 \\
\hline $\mathrm{SHC}^{\mathrm{a}}$ & 0.6 & 1.1 & 0.5 & 0.4 & 3.6 & 5.3 & 2.4 & 0.1 \\
\hline Site & \multicolumn{8}{|c|}{ Concentration of manganese $(\mathrm{mg} / \mathrm{L})$} \\
\hline MOB & 0.3 & 0.1 & 0.1 & 0.0 & 0.4 & 0.1 & 0.2 & 0.2 \\
\hline MOC & 0.0 & 0.1 & 0.0 & 0.0 & 4.3 & 0.3 & 0.2 & 0.2 \\
\hline MGS & 0.0 & bdl & 0.0 & 0.1 & 1.0 & 0.0 & 0.0 & 0.1 \\
\hline MGD & 0.1 & bdl & 0.0 & 0.0 & 0.6 & 0.4 & 0.2 & 0.2 \\
\hline SAA & 0.0 & bdl & 0.0 & 0.0 & 0.8 & 0.2 & 0.0 & 0.1 \\
\hline $\mathrm{BAB}$ & bdl & bdl & 0.3 & 0.1 & 0.2 & 0.1 & 0.2 & 0.1 \\
\hline BAG & 0.1 & bdl & 0.0 & 0.2 & 0.2 & 0.2 & 0.3 & 0.2 \\
\hline DAB & 0.3 & 0.1 & 0.0 & 0.1 & 5.6 & 1.0 & 0.7 & 1.0 \\
\hline DAC & 0.2 & 0.1 & 0.1 & 0.0 & 0.8 & 0.2 & 0.2 & 0.2 \\
\hline PAL & 0.2 & 0.2 & 0.9 & 0.3 & 0.4 & 0.6 & 0.5 & 0.6 \\
\hline ASA & 0.0 & bdl & 0.0 & 0.2 & 0.1 & 0.1 & 0.2 & 0.0 \\
\hline KAK & 0.0 & 0.0 & 0.0 & 0.1 & 0.3 & 0.1 & 0.2 & 0.1 \\
\hline $\mathrm{SHC}^{\mathrm{a}}$ & 0.2 & 0.2 & 0.4 & 0.2 & 0.5 & 1.0 & 1.2 & 1.1 \\
\hline Site & \multicolumn{8}{|c|}{ Concentration of chloride $(\mathrm{mg} / \mathrm{L})$} \\
\hline MOB & 201 & 142 & 127 & 130 & 856 & 163 & 260 & 211 \\
\hline MOC & 1,017 & 439 & 755 & 1,832 & 4,628 & 1,704 & 572 & 666 \\
\hline MGS & 65 & 56 & 67 & 41 & 1,229 & 479 & 142 & 48 \\
\hline MGD & 104 & 65 & 92 & 52 & 340 & 228 & 82 & 51 \\
\hline SAA & 20 & 37 & 22 & 15 & 1,615 & 1,056 & 8 & 246 \\
\hline BAB & 772 & 155 & 3,384 & 1,482 & 678 & 296 & 369 & 393 \\
\hline BAG & 256 & 101 & 206 & 133 & 294 & 243 & 226 & 200 \\
\hline DAB & 674 & 640 & 887 & 693 & 2,988 & 781 & 735 & 706 \\
\hline DAC & 448 & 314 & 452 & 397 & 845 & 495 & 375 & 450 \\
\hline PAL & 495 & 407 & 632 & 480 & 1,524 & 1,395 & 1,132 & 1,228 \\
\hline ASA & 287 & 307 & 733 & 614 & 295 & 356 & 681 & 521 \\
\hline KAK & 108 & 80 & 101 & 27 & 201 & 66 & 147 & 65 \\
\hline $\mathrm{SHC}^{\mathrm{a}}$ & 40 & 107 & 13 & 18 & 973 & 1,267 & 1,634 & 1,618 \\
\hline
\end{tabular}

${ }^{\mathrm{a}}$ Sites are not abstracted for water supply.

inadequate development of the infiltration wells. Other mechanisms that may contribute to clogging are discussed next.

Swelling and dispersion of clay, especially reactive clays such as montmorillonite (smectite) is a well-known risk for clogging, where as little as $5 \%$ of clay in the storage zone can result in a rapid degradation of ASR performance (Brown and Silvey 1973). The target aquifer is composed of unconsolidated fine to medium sand with variable amounts of clay coatings (Table 1). Illite is ubiquitous in both the Ganges and Brahmaputra rivers, with the Ganges sediment having high smectite $(\sim 30 \%)$ while the 


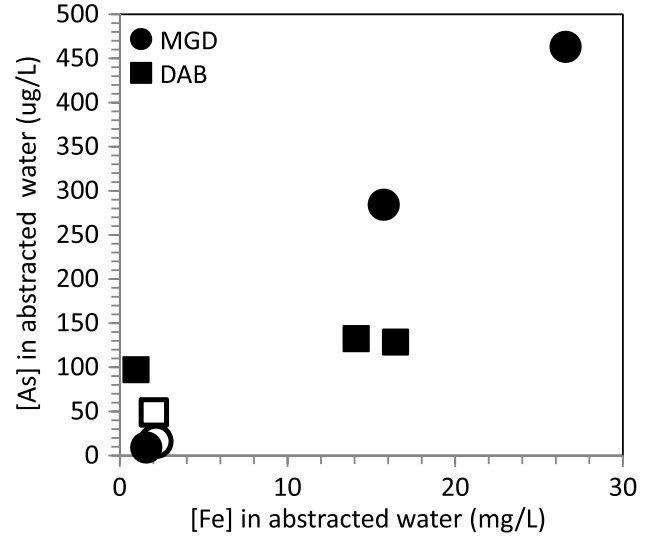

Fig. 5. Laboratory measurements of concentrations of Fe versus As in abstracted well water collected from sites DAB and MGD that showed significant $\mathrm{Fe}(>10 \mathrm{mg} / \mathrm{L})$ and As $(>100 \mathrm{~g} / \mathrm{L})$ during the 1 st year of infilration in 2012 moonson season (Table 4); open symbols indicate much lower Fe and As levels during the abstraction period in March, 2013, suggesting immobilization of Fe and As released during infiltration
Brahmaputra's has low smectite ( 5\%) (Heroy et al. 2003). Clay in the Meghna flood plain of Bangladesh is mostly kaolinite (Hasan et al. 2009). Clay mineralogy data for these sites is yet to be determined but the presence of smectite is likely. In addition, clays may also swell due to cation exchange when fresh water is introduced to brackish silici-clastic aquifers (Maliva and Missimer 2010). Monitoring major cation composition changes in groundwater over time at these sites can help to ascertain this possibility.

There is also potential for chemical clogging due to precipitation of Fe and Mn (Table 4). There are no simple associations between the operational infiltration rate and $\mathrm{Fe}$ or $\mathrm{Mn}$ concentrations in recovered water, although this observation is limited by only four dates when $\mathrm{Fe}$ and $\mathrm{Mn}$ concentrations were measured. Regular monitoring of $\mathrm{Fe}$ and $\mathrm{Mn}$, along with other redox-sensitive parameters, is needed to assess the risk of clogging from precipitation of oxyhydroxide and carbonate phases because the geochemical environment may be favorable to such mineral formation (Moorman et al. 2002).

The high nutrient and natural organic matter content (unpublished data) in pond water suggest that biological clogging is a
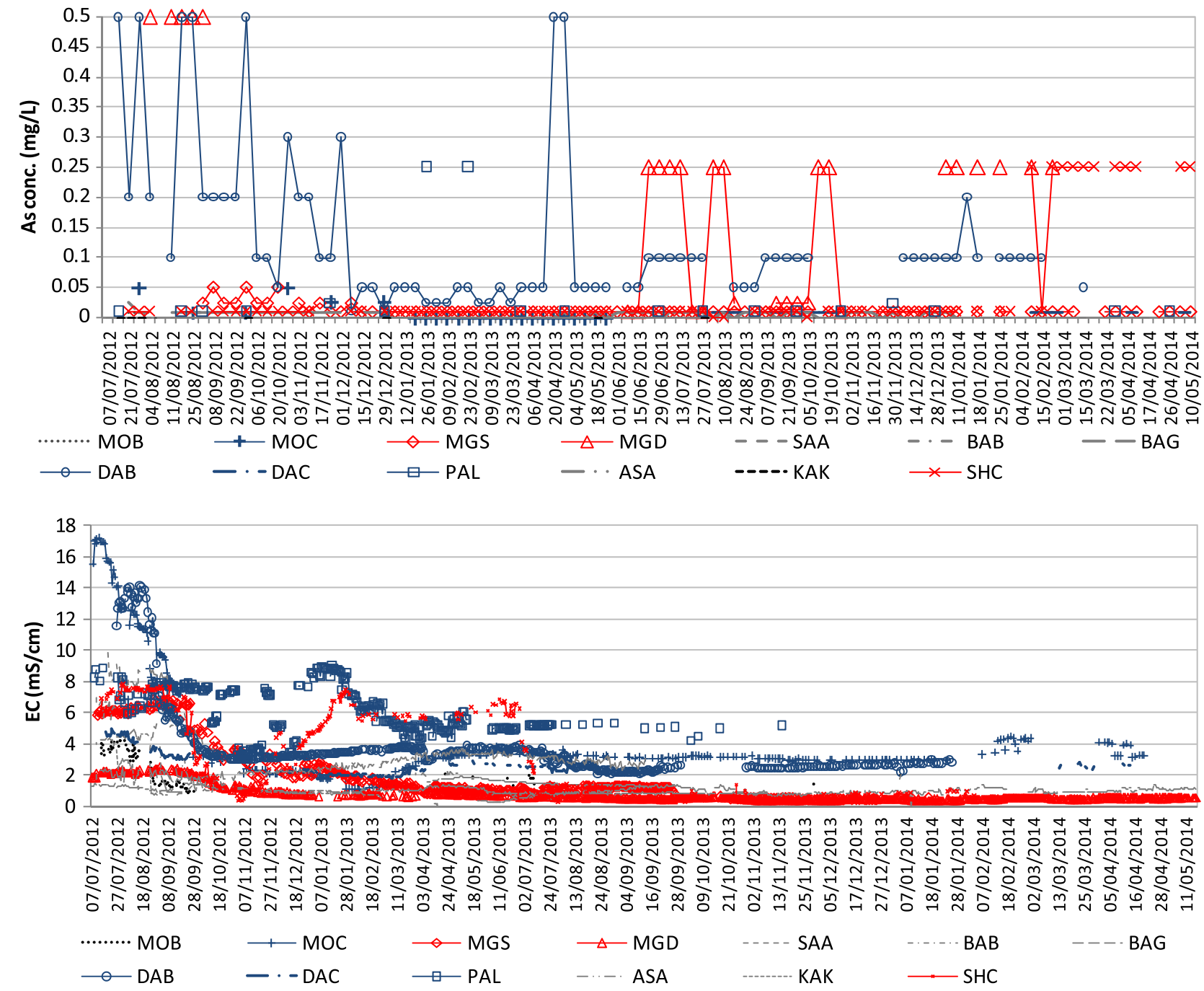

Fig. 6. Variations of As concentrations in abstracted water at 13 sites monitored by ITS EconoQuick As test kits between July 2012 and May 2014 (upper panel) and variations of EC (lower panel). Six sites with any As values $>0.05 \mathrm{mg} / \mathrm{L}$ were indicated by symbols; four sites MOC, DAB, DAC, and PAL have high EC values $(>2 \mathrm{mS} / \mathrm{cm})$; sites MGD, DAB, and SHC display persistent high levels of As ( $>0.1 \mathrm{mg} / \mathrm{L})$ during the abstraction period, with sites MGD and SHC the most dangerous because the water also had low EC 
concern. On the basis of sand column tests, Okubo and Matsumoto (1983) suggested that source water should have a TDS of $<2 \mathrm{mg} / \mathrm{L}$ and soluble organic carbon concentration of $<10 \mathrm{mg} / \mathrm{L}$ in order to maintain a high infiltration rate. That biological clogging has not emerged as an issue at our sites may be due to one or more of the following factors: the short time period of operation; the small quantity of infiltration so far, and the frequent backwashing. Although pond waters are rich in nutrients such as nitrate (1-60 mg/L) and phosphate $(0.2-1.5 \mathrm{mg} / \mathrm{L})$, so are the ambient groundwaters. Thus in that sense, there is not a great change due to infiltration besides introducing natural organic matter that may have higher reactivity in pond water (Mladenov et al. 2010).

\section{Implications and Challenges for Upscaling}

Although in its infancy, freshening of the brackish groundwater (Fig. 6) and recovery of fresh water (Table 1) was achieved with one season of infiltration at 11 out of 13 pilot sites. There has also been significant reduction in fecal indicator bacteria (Table 3) and turbidity (Table 2), although increasing arsenic (Table 4 and Fig. 6) is concerning and requires management. Despite the high physical clogging risk due to source water turbidity, management has so far been effective in maintaining average operational infiltration rates of 3-6 $\mathrm{m}^{3}$ per day over one year (Fig. 3).

In addition to the risks of clay swelling and chemical and biological clogging, there are general limitations to the applicability of ASR using ponds as source water. First, fresh water ponds are scarce and valuable to local communities, hence future ASR systems will need to secure alternative fresh water sources by effectively capturing the rain. Second, because power outages are common, the design could benefit from either greater reliance on gravity or incorporation of solar-powered pumping. Third, management of clogging is time consuming and labor intensive and requires sustained community engagement. Fourth, the operational cost of abstraction, together with the associated financing mechanisms, need to be carefully assessed with respect to people's ability to pay. Fifth, appropriate institutional arrangements between communities, the private sector, nongovernment organizations, and local governments need to be established, especially for monitoring water quality. We are cautiously optimistic that these challenges can be met by the industrious coastal Bangladeshi community.

\section{Conclusions}

Pilot testing of low-cost, small-scale ASR schemes that infiltrate pond water into shallow brackish aquifers has demonstrated the potential of ASR to provide potable water in acutely water scarce areas of coastal Bangladesh. Short-term clogging risks from suspended particles in pond water have been minimized through two stages of sand filtration and by frequent manual washing. Long-term clogging from clay swelling and chemical and biological mechanisms requires further investigation, along with the need to disinfect and to monitor As content in recovered water to ensure safety.

\section{Acknowledgments}

This paper reflects the view of the authors only and not that of UNICEF. We thank UNICEF staff Kamrul Alam, Lalit Patra, Astrid van Agthoven, Hans Spruijt, and Carel de Rooy for crucial support during the incubation stage. We thank UNICEF for funding this work. We are grateful for the rural communities for allowing us to test ASR systems, for field staff for monitoring the performance of the systems, and for Richard Johnston of EAWAG in providing chemical analysis of water samples.

\section{References}

Ahmed, K. M., et al. (2004). "Arsenic enrichment in groundwater of the alluvial aquifers in Bangladesh: An overview." Appl. Geochem., 19(2), 181-200.

Ahmed, N., Allison, E. H., and Muir, J. F. (2009). "Rice fields to prawn farms: A blue revolution in southwest Bangladesh?" Aquacult. Int., 18, 555-574.

Bahar, M. M., and Reza, M. S. (2010). "Hydrochemical characteristics and quality assessment of shallow groundwater in a coastal area of Southwest Bangladesh.” Environ. Earth Sci., 61(5), 1065-1073.

Bangladesh Water Development Board (BWDB). (2013). "Establishment of monitoring network and mathematical model study to assess salinity intrusion in groundwater in the coastal area of Bangladesh due to climate change." Synthesis Rep., Bangladesh Water Development Board, Dhaka, Bangladesh.

Barker, J. L. (2013). "Numerical evaluation of community scale aquifer storage, transfer and recovery technology." M.Sc. thesis, Univ. of Western Ontario, London, ON, Canada.

British Geological Survey (BGS) and Department of Public Health Engineering (DPHE). (2001). "Arsenic contamination of groundwater in Bangladesh." British Geological Survey Rep. WC/00/19, D. G. Kinniburgh and P. L. Smedley, eds., British Geological Survey, Keyworth, U.K.

Brown, D. L., and Silvey, W. D. (1973). "Underground storage and retrieval of freshwater from a brackish water aquifer." Underground Waste Management and Artificial Recharge: Proc., 2nd Int. Symp., J. Braunstein, ed., U.S. Geological Survey, New Orleans, 379-419.

Datta, S., et al. (2011). "Perennial ponds are not an important source of water or dissolved organic matter to groundwaters with high arsenic concentrations in West Bengal, India.” Geophys. Res. Let., 38, L20404.

Department of Environment (DOE). (1993). "Assessment of the vulnerability of coastal areas to sea level rise and other effects of global climate change-Pilot study Bangladesh.” Government of Bangladesh, Dhaka, Bangladesh.

French Geological Survey (BRGM). (2005). "Groundwater resources and hydro-geological investigations in and around Khulna City." Local Government Engineering Dept., Government of Bangladesh, Dhaka, Bangladesh.

Gale, I. N., et al. (2006). "Managed aquifer recharge: An assessment of its role and effectiveness in watershed management." British Geological Survey Commissioned Rep. CR/06/107N, British Geological Survey, Environmental Science Centre, Nottingham, U.K.

George, C. M., et al. (2012). "Evaluation of an arsenic test kit for rapid well screening in Bangladesh." Environ. Sci. Technol., 46(20), 11213-11219.

Hasan, M. A., et al. (2009). "Geochemistry and mineralogy of shallow alluvial aquifers in Daudkandi upazila in the Meghna flood plain, Bangladesh." Environ. Geol., 57(3), 499-511.

Heroy, D. C., Kuehl, S. A., and Goodbred, S. L. (2003). "Mineralogy of the ganges and Brahmaputra rivers: Implications for river switching and late quaternary climate change." Sediment. Geol., 155(3-4), 343-359.

Holländer, H. M., Mull, R., and Panda, S. N. (2009). “A concept for managed aquifer recharge using ASR-wells for sustainable use of groundwater resources in an alluvial coastal aquifer in eastern India." Phys. Chem. Earth, Parts A/B/C, 34(4-5), 270-278.

Hoque, B. A. (1999). "Biological contamination of tubewell water." Proc., 8th Annual Scientific Conf. of ICDDR, B, International Centre for Diarrhoeal Disease Research, Bangladesh, Dhaka, Bangladesh.

Islam, M. S., and Tooley, M. J. (1999). "Coastal and sea-level changes during the Holocene in Bangladesh.” Quat. Int., 55(1), 61-75. 
Jung, H. B., Bostick, B. C., and Zheng, Y. (2012). "Field, experimental, and modeling study of arsenic partitioning across a redox transition in a Bangladesh aquifer." Environ. Sci. Technol., 46(3), 1388-1395.

Khan, M. M., Sakauchi, F., Sonoda, T., Washio, M., and Mori, M. (2003). "Magnitude of arsenic toxicity in tube-well drinking water in Bangladesh and its adverse effects on human health including cancer: Evidence from a review of the literature." Asian Pac. J. Cancer Prev., 4(1), 7-14.

Khanom, S., and Salehin, M. (2012). "Salinity constraints to different water uses in coastal areas of Bangladesh: A case study." Bangladesh J. Sci. Res., 25(1), 33-42.

Kodaka, H., Mizuochi, S., Teramura, H., and Nirazuka, T. (2006). "Comparison of the compact dry EC with the most probably number method (AOAC Offical Method 966.24) for enumeration of Escherichia coli and coliform bacteria in raw meats." J. AOAC Int., 89(1), 100-114.

Luby, S. P., Gupta, S. K., Sheikh, M. A., Johnston, R. B., Ram, P. K., and Islam, M. S. (2008). "Tubewell water quality and predictors of contamination in three flood-prone areas in Bangladesh." J. Appl. Microbiol., 105(4), 1002-1008.

Maliva, R. G., and Missimer, T. M. (2010). "Aquifer storage and recovery and the development of sustainable water supplies." IDA J., 2, 74-80.

Maliva, R. G., and Missimer, T. M. (2010). "Aquifer storage and recovery and managed aquifer recharge using wells: Planning, hydrogeology, design, and operation." Methods in water resources evaluation, Schlumberger Water Services, TX.

Martin, R., ed. (2013). "Clogging issues associated with managed aquifer recharge methods." IAH Commission on Managing Aquifer Recharge, 〈www.iah.org/recharge/clogging.htm〉.

McArthur, J. M., Ravenscroft, P., and Sracek, O. (2011). "Aquifer arsenic source." Nature Geoscience, 4(10), 655-656.

McQuarrie, J. P., and Carlson, K. (2003). "Secondary benefits of aquifer storage and recovery: Disinfection by-product control." J. Environ. Eng., 10.1061/(ASCE)0733-9372(2003)129:5(412), 412-418.

Mladenov, N., et al. (2010). "Dissolved organic matter sources and consequences for iron and arsenic mobilization in Bangladesh aquifers." Environ. Sci. Technol., 44, 123-128.

Moorman, J. H. N., Colin, M. G., and Stuyfzand, P. J. (2002). "Iron precipitation clogging of a recovery well following nearby deep well injection." Management of aquifer recharge for sustainability, P. J. Dillon, ed., Balkema, Lisse, Netherlands, 209-214.
Morgan, J. P., and McIntire, W. G. (1959). "Quaternary geology of the Bengal basin, east Pakistan, and India." Geol. Soc. Am. Bull., 70(3), 319-342.

Neumann, R. B., Ashfaque, K. N., Badruzzaman, A. B. M., Ashraf Ali, M., Shoemaker, J. K., and Harvey, C. F. (2010). "Anthropogenic influences on groundwater arsenic concentrations in Bangladesh." Nat. Geosci., $3(1), 46-52$.

Okubo, T., and Matsumoto, J. (1983). "Biological clogging of sand and changes of organic-constituents during artificial recharge." Water Res., 17(7), 813-821.

Pavelic, P., Dillon, P. J., and Barry, K. E. (2007a). "Management of clogging for reclaimed water ASR in a carbonate aquifer." Management of Aquifer Recharge for Sustainability: Proc., 6th Int. Symp. on Managed Aquifer Recharge of Groundwater, P. Fox, ed., Acacia Publishing, Arizona, 148-161.

Pavelic, P., Dillon, P. J., Barry, K. E., Vanderzalm, J. L., Correll, R. L., and Rinck-Pfeiffer, S. M. (2007b). "Water quality effects on clogging rates during reclaimed water ASR in a carbonate aquifer." J. Hydrol., $334(1-2), 1-16$.

Pavelic, P., Nicholson, B. C., Dillon, P. J., and Barry, K. E. (2005). "Fate of disinfection by-products in groundwater during aquifer storage and recovery with reclaimed water." J. Contam. Hydrol., 4, 351-373.

Pyne, R. D. G. (1994). "Seasonal storage of reclaimed water and surface water in brackish aquifers using aquifer storage recovery wells." Artificial Recharge of Groundwater II: Proc., 23rd Int. Symp. on Artificial Recharge of Ground Water, A. I. Johnson and R. D. G. Pyne, eds., ASCE, 282-298.

Pyne, R. D. G. (2002). "Aquifer storage recovery wells: The path ahead." Florida Water Resour. J., 19-27.

Pyne, R. D. G. (2005). Aquifer storage and recovery: A guide to groundwater recharge through wells, ASR Press, FL.

Sengupta, S., et al. (2008). "Do ponds cause arsenic-pollution of groundwater in the Bengal basin? An answer from West Bengal." Environ. Sci. Technol., 42(14), 5156-5164.

Umitsu, M. (1993). "Late quaternary sedimentary environments and landforms in the Ganges Delta." Sediment. Geol., 83(3-4), 177-186.

Wasserman, G. A., et al. (2006). "Water manganese exposure and children's intellectual function in Araihazar, Bangladesh." Environ. Health Perspect., 114(1), 124-129. 